\title{
Alkamides from Anacyclus pyrethrum L. and Their in Vitro Antiprotozoal Activity
}

\author{
Julia B. Althaus ${ }^{1,+}$, Claudine Malyszek ${ }^{1,+}$, Marcel Kaiser ${ }^{2,3}$, Reto Brun ${ }^{2,3}$ and \\ Thomas J. Schmidt ${ }^{1, *}$ \\ 1 Institut für Pharmazeutische Biologie und Phytochemie (IPBP), University of Münster, PharmaCampus, \\ Corrensstraße 48, Münster D-48149, Germany; julia.althaus@uni-muenster.de (J.B.A.); \\ cmalyszek@brial.com (C.M.) \\ 2 Swiss Tropical and Public Health Institute (Swiss TPH), Socinstraße 57, Basel CH-4002, Switzerland; \\ marcel.kaiser@unibas.ch (M.K.); reto.brun@unibas.ch (R.B.) \\ 3 University of Basel, Petersplatz 1, Basel CH-4003, Switzerland \\ * Correspondence: thomschm@uni-muenster.de; Tel.: +49-251-83-33378; Fax: +49-251-83-38341 \\ + Part of doctoral thesis of J.B.A. and MSc thesis of C.M.
}

Academic Editor: Derek J. McPhee

Received: 28 April 2017; Accepted: 11 May 2017; Published: 12 May 2017

\begin{abstract}
In our ongoing study to evaluate the antiprotozoal activity of alkamides from Asteraceae, a dichloromethane extract from the roots of Anacyclus pyrethrum L. showed a moderate in vitro activity against the NF54 strain of Plasmodium falciparum and against Leishmania donovani (amastigotes, MHOM/ET/67/L82 strain). Seven pure alkamides and a mixture of two further alkamides were isolated by column chromatography followed by preparative high performance liquid chromatography. The alkamides were identified by mass- and NMR-spectroscopic methods as tetradeca-2E,4E-dien-8,10-diynoic acid isobutylamide (anacycline, 1), deca-2E,4E-dienoic acid isobutylamide (pellitorine, 2), deca-2E,4E,9-trienoic acid isobutylamide (3), deca-2E,4E-dienoic acid 2-phenylethylamide (4), undeca-2E,4E-dien-8,10-diynoic acid isopentylamide (5), tetradeca-2E,4E,12Z-trien-8,10-diynoic acid isobutylamide (6), and dodeca-2E,4E-dien acid 4-hydroxy-2-phenylethylamide (7). Two compounds-undeca-2E,4E-dien-8,10-diynoic acid 2-phenylethylamide (8) and deca-2E,4E-dienoic acid 4-hydroxy-2-phenylethylamide (9)-were isolated as an inseparable mixture (1:4). Compounds 3, 4, and 5 were isolated from Anacyclus pyrethrum L. for the first time. While compounds 4 and 5 were previously known from the genus Achillea, compound 3 is a new natural product, to the best of our knowledge. All isolated alkamides were tested in vitro for antiprotozoal activity against Plasmodium falciparum, Trypanosoma brucei rhodesiense, Trypanosoma cruzi, and Leishmania donovani and for cytotoxicity against L6 rat skeletal myoblasts.
\end{abstract}

Keywords: Anacyclus pyrethrum L.; antiprotozoal activity; alkamide; Plasmodium falciparum; Trypanosoma brucei rhodesiense; Trypanosoma cruzi; Leishmania donovani

\section{Introduction}

Alkamides represent a class of natural products with considerable structural diversity and a broad spectrum of bioactivities [1]. In a previous study, alkamides from Achillea ptarmica L. (sneezewort yarrow, Asteraceae) showed activity against Plasmodium falciparum (Pf) and Trypanosoma brucei rhodesiense (Tbr), causative agents of tropical malaria (Pf) and human African trypanosomiasis (HAT, "Sleeping Sickness"; Tbr), respectively. However, the activity of the isolated alkamides could not conclusively explain the high activity of the tested dichloromethane extract against T. $b$. rhodesiense $\left(\mathrm{IC}_{50} 0.67 \mu \mathrm{g} / \mathrm{mL}\right)$ [2]. Recently, an alkamide structurally related to those found in A. ptarmica but with 
an endoperoxide structure was isolated from Acmella ciliata, (also Asteraceae) and showed considerable antiplasmodial activity against $P f[3]$.

These studies on alkamides from Asteraceae were extended to Anacyclus pyrethrum L. and its alkamide constituents. From a phylogenic point of view, Anacyclus pyrethrum is closely related to Achillea ptarmica L. within the tribe Anthemideae of Asteraceae [4-6], and both species are known to contain a structural pattern similar to alkamides [7]. A. pyrethrum has been known since ancient times for its use as medicinal plant used-among other ailments—against recurring fevers (De Materica Medica [8]), and it was mentioned in a review by Adams as one of the plants used against malaria during the Renaissance (16th and 17th century) [9]. In a bioactivity study associated with the mentioned review, antiplasmodial activity was reported for an ethyl acetate extract of $A$. pyrethrum roots, but without mentioning the level of activity in terms of an $\mathrm{IC}_{50}$ value and without specification of the active constituents [10]. We recently reported on the antiprotozoal $\mathrm{IC}_{50}$ values of a dichloromethane extract from this plant drug, including a value of $3 \mu \mathrm{g} / \mathrm{mL}$ for the activity against Plasmodium falciparum [2].

The aim of the present study was therefore to evaluate the antiprotozoal activity of the alkamides in the roots of A. pyrethrum.

\section{Results and Discussion}

\subsection{Isolation and Structural Characterization of the Alkamides}

The major alkamides of A. pyrethrum roots were isolated from the dichloromethane extract by column chromatography (CC) on silica with an n-hexane-ethylacetate gradient followed by preparative high performance liquid chromatography (HPLC) of representative CC-fractions (XV, XIX, XX and XXII) selected on the basis of their UHPLC/+ESI QqTOF MS chromatograms (see Figure 1).

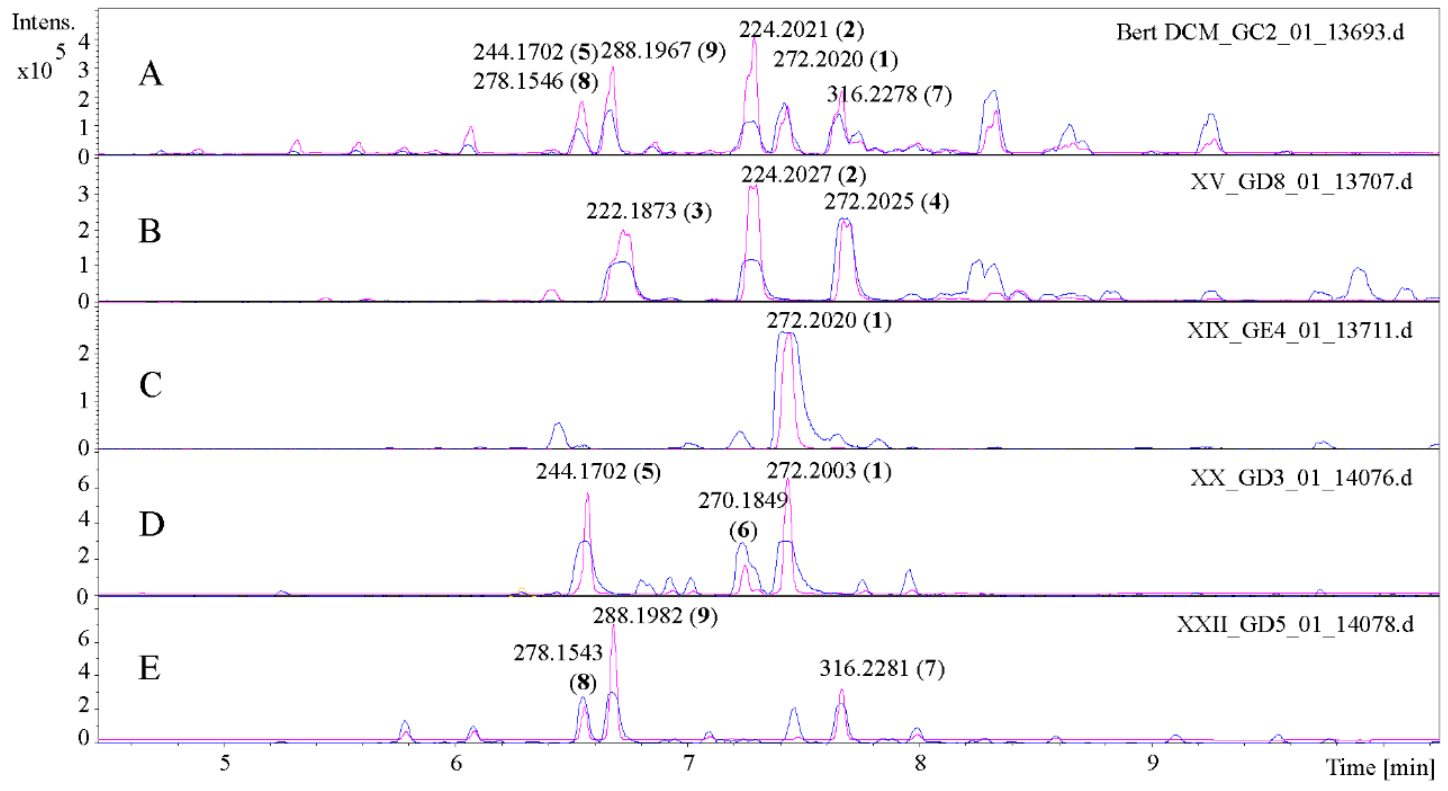

Figure 1. UHPLC/+ESI QqTOF MS-MS chromatograms of the $\mathrm{CH}_{2} \mathrm{Cl}_{2}$-extract of Anacyclus pyrethrum L. (A) $\mathrm{c}=10 \mathrm{mg} / \mathrm{mL}$ and the selected fractions (B-E) $\mathrm{c}=5 \mathrm{mg} / \mathrm{mL}$. (B) fraction $\mathrm{XV}$, (C) fraction XIX, (D) fraction $X X$, and (E) fraction XXII. All peaks are labelled with the measured $m / z$ values and compound numbers. Blue represents base peak chromatogram $m / z$ 100-500, and magenta represents base peak UV-chromatogram at $260 \mathrm{~nm}$.

The alkamides were identified by their exact molecular masses determined by UHPLC/ +ESI-QTOF-MS/MS and by NMR spectroscopy. 
The main component of fraction XIX (Figure 1, chromatogram C) with $m / z 272.2020[\mathrm{M}+\mathrm{H}]^{+}$ was identified by its mass and NMR data as tetradeca-2E,4E-dien-8,10-diynoic acid isobutylamide (anacycline, 1) in direct comparison with the compound previously isolated from A. ptarmica and literature data [2,11]. Three compounds were isolated from fraction XV (Figure 1, chromatogram B). Compound $2\left(m / z 224.2027[\mathrm{M}+\mathrm{H}]^{+}\right)$was identified (in the same manner as $\left.\mathbf{1}\right)$ as deca-2E,4E-dienoic acid isobutylamide (pellitorine) $[2,12]$. Compound $3\left(m / z 222.1873[\mathrm{M}+\mathrm{H}]^{+}\right)$displayed a similar ${ }^{1} \mathrm{H}-\mathrm{NMR}$ spectrum as 2, but with signals typical of a pair of germinal olefinic protons at position C-10 (Figure S1). All proton resonances were assigned to the corresponding ${ }^{13} \mathrm{C}-\mathrm{NMR}$ signals (Figure S2) by an HSQC experiment (Figures S3 and S4), and the ${ }^{1} \mathrm{H} /{ }^{1} \mathrm{H}$ COSY as well as ${ }^{1} \mathrm{H} /{ }^{13} \mathrm{C} \mathrm{HMBC}$ spectra (Figures S5-S7) allowed unambiguous assignment of structure of 3 as deca-2E,4E,9-trienoic acid isobutylamide (9,10-dehydropellitorine; Figure 2)—a new natural product to the best of our knowledge.<smiles>CNCC(C)C</smiles>

A<smiles>CNCCC(C)C</smiles>

B<smiles>CNCCc1ccccc1</smiles>

C<smiles>CNCCc1ccc(O)cc1</smiles><smiles>[R]C#CC#CCC/C=C/C=C/C([R])=O</smiles><smiles>[R]CCCCC/C=C\C=C\C([R])=O</smiles>

$\begin{array}{llllll}\mathrm{R}_{1}: & \mathbf{A} & \mathbf{C} & \mathbf{B} & \mathbf{D} & \mathbf{D} \\ \mathrm{R}_{2}: & \mathrm{H} & \mathrm{H} & \mathrm{CH}_{3} & \mathrm{C}_{2} \mathrm{H}_{5} & \mathrm{H} \\ & \mathbf{2} & \mathbf{4} & \mathbf{5} & \mathbf{7} & \mathbf{9}\end{array}$<smiles>[Y4]C=CC#CC#CCC/C=C\C=C\C([R])=O</smiles><smiles>[R17]C(=O)/C=C/C=C/CCCC=[V]</smiles>

$\mathrm{R}_{1}: \mathbf{A}$ 3

Figure 2. Structures of the isolated alkamides from A. pyrethrum. Deca-2E,4E,9-trienoic acid isobutylamide $(9,10$-dehydropellitorine; compound 3$)$ is a new natural product.

A further compound with a molecular mass of $272 \mathrm{amu}\left([\mathrm{M}+\mathrm{H}]^{+}\right.$at $\left.m / z 272.2025\right)$ was identified as deca-2E,4E-dienoic acid 2-phenylethylamide (4) by its ${ }^{1} \mathrm{H}$-spectrum (Figure S8) in comparison with literature [13]. The compound was known from Achillea wilhelmsii but is now described as a constituent of A. pyrethrum for the first time.

Fraction XX (Figure 1, chromatogram D) contained-besides further anacycline $(\mathbf{1}, m / z 272.2003$ $\left.[\mathrm{M}+\mathrm{H}]^{+}\right)$- two further compounds which could be identified as undeca-2E,4E-dien-8,10-diynoic acid isopentylamide $\left(5, m / z 244.1702[\mathrm{M}+\mathrm{H}]^{+}\right)$and tetradeca-2E,4E,12Z-trien-8,10-diynoic acid isobutylamide $\left(6, m / z 270.1849[\mathrm{M}+\mathrm{H}]^{+}\right)$. Compound 5 was identified by comparison of its NMR spectra (Figure S9), which were in full agreement with literature data [11] reported after isolation from Achillea ptarmica $\mathrm{L}$. This is the first report on the occurrence of $\mathbf{5}$ in A. pyrethrum. In the case of compound 6, it was reported in the literature that the all-E-isomer (tetradeca-2E,4E,12E-trien-8,10-diynoic acid isobutylamide) is a constituent of Anacyclus pyrethrum L. [1,14]. In our investigation, the isolated compound was unambiguously found to be the Z-isomer with regard to the C-12-C-13 double bond, since the coupling 
constant of $\mathrm{H}-12$ and $\mathrm{H}-13$ was $11 \mathrm{~Hz}$. Since no NMR data proving the double bond geometry were reported in the original literature [14], it cannot be excluded that the reported constituent of A. pyrethrum was identical with compound 6 . It could be possible, however, that both isomers occur in the plant.

In fraction XXII (Figure 1, chromatogram E), three compounds (7-9) with $[\mathrm{M}+\mathrm{H}]^{+}$adduct ions at $m / z$ 316.2281, 278.1543 and 288.1982, respectively, were isolated, with the latter two in a mixture of approximately 1:4. Their NMR spectra in comparison with literature [15] allowed unambiguous identification as dodeca-2E,4E-dien acid 4-hydroxy-2-phenylethylamide (7), undeca-2E,4E-dien-8,10-diynoic acid 2-phenethylamide (8), and deca-2E,4E-dienoic acid 4-hydroxy-2phenylethylamide (9), respectively, all known constituents of A. pyrethrum [15].

\subsection{Antiprotozoal Activity of the Isolated Alkamides}

The $\mathrm{IC}_{50}$ values for the in vitro antiprotozoal activity against Trypanosoma brucei rhodesiense (Tbr), Trypanosoma cruzi (Tc), Leishmania donovani $(L d)$ and Plasmodium falciparum (Pf), as well as the cytotoxicity against L6 rat skeletal myoblasts of the crude dichloromethane extract from A. pyrethrum roots and of anacycline and pellitorine ( $\mathbf{1}$ and $\mathbf{2})$ were tested earlier under identical conditions, and the results were reported in our earlier study [2]. The respective data of the isolated compounds 3-7 as well as the 1:4 mixture of $\mathbf{8}+\mathbf{9}$ were determined in this study and are reported in Table 1 .

Table 1. In vitro antiprotozoal and cytotoxic activity ( $\mathrm{IC}_{50}$ values in $\mu \mathrm{g} / \mathrm{mL}$; values in $\mu \mathrm{M}$ of pure compounds are reported in brackets) of the dichloromethane (DCM) extract from Anacyclus pyrethrum roots and of the isolated alkamides (3-5). Selectivity indices (SIs) represent the ratio of cytotoxic over antiprotozoal $\mathrm{IC}_{50}$ values. Data are means of two independent determinations \pm deviation from mean value. The in vitro activity data of $\mathbf{1}$ (anacycline) and $\mathbf{2}$ (pellitorine) was previously reported by us [2].

\begin{tabular}{|c|c|c|c|c|c|c|c|c|}
\hline Sample & $T b r^{1}$ & $T c^{2}$ & $L d^{3}$ & $P f^{4}$ & Cytotox 5 & $\begin{array}{c}\text { SI } \\
T b r\end{array}$ & $\begin{array}{l}\text { SI } \\
L d\end{array}$ & $\begin{array}{l}\text { SI } \\
P f\end{array}$ \\
\hline Pos. contr. & $\begin{array}{c}0.003 \pm 0.001 \\
(0.008)\end{array}$ & $\begin{array}{c}0.439 \pm 0.094 \\
(1.688)\end{array}$ & $\begin{array}{c}0.127 \pm 0.052 \\
(0.312)\end{array}$ & $\begin{array}{c}0.080 \pm 0.003 \\
(0.250)\end{array}$ & $\begin{array}{c}0.008 \pm 0.001 \\
(0.019)\end{array}$ & & & \\
\hline DCM extr. ${ }^{6}$ & $>10$ & $8.83 \pm 0.75$ & $4.22 \pm 1.57$ & $3.04 \pm 0.07$ & $13.4 \pm 3.2$ & $>1.3$ & 3.2 & 4.4 \\
\hline 3 & $\begin{array}{c}2.91 \pm 0.21 \\
\quad(13.2)\end{array}$ & $\begin{array}{l}39.9 \\
(181)\end{array}$ & $\begin{array}{c}4.77 \pm 1.02 \\
(21.6)\end{array}$ & $\begin{array}{c}7.13 \pm 0.63 \\
(32.2)\end{array}$ & $\begin{array}{c}16.7 \pm 0.1 \\
(75.3)\end{array}$ & 5.7 & 3.5 & 2.3 \\
\hline 4 & $\begin{array}{c}4.03 \\
(14.9)\end{array}$ & $\begin{array}{c}5.02 \pm 0.05 \\
(18.5)\end{array}$ & $\begin{array}{c}2.97 \pm 0.54 \\
(11.0)\end{array}$ & $\begin{array}{c}>5 \\
(>18)\end{array}$ & $\begin{array}{l}7.88 \\
(29.1)\end{array}$ & 2.0 & 2.7 & $>1.6$ \\
\hline 5 & $\begin{array}{c}4.59 \pm 0.39 \\
(18.9)\end{array}$ & $\begin{array}{c}16.3 \pm 0.3 \\
(66.9)\end{array}$ & $\begin{array}{c}4.04 \pm 0.71 \\
(16.6)\end{array}$ & $\begin{array}{c}10.3 \pm 1.4 \\
(42.5)\end{array}$ & $\begin{array}{l}28.2 \pm 6.9 \\
\quad(116)\end{array}$ & 6.2 & 7.0 & 2.7 \\
\hline 6 & $\begin{array}{c}6.37 \pm 0.94 \\
(23.7)\end{array}$ & $\begin{array}{c}38.8 \pm 2.1 \\
\quad(144)\end{array}$ & $\begin{array}{c}5.04 \pm 1.17 \\
(18.7)\end{array}$ & $\begin{array}{c}7.19 \pm 0.49 \\
(26.7)\end{array}$ & $\begin{array}{c}19.4 \pm 1.7 \\
(72.2)\end{array}$ & 3.1 & 3.9 & 2.7 \\
\hline 7 & $\begin{array}{c}2.26 \pm 0.18 \\
(7.17)\end{array}$ & $\begin{array}{c}1.88 \\
(5.97)\end{array}$ & $\begin{array}{c}4.19 \pm 1.64 \\
(13.3)\end{array}$ & $\begin{array}{c}3.18 \pm 0.20 \\
(10.1)\end{array}$ & $\begin{array}{c}0.19 \pm 0.05 \\
(0.69)\end{array}$ & 0.1 & $<0.1$ & $<0.1$ \\
\hline $8+9(1: 4)$ & $1.66 \pm 0.12$ & 3.90 & $5.31 \pm 0.53$ & $7.64 \pm 2.57$ & $2.47 \pm 0.36$ & 1.5 & 0.5 & 0.3 \\
\hline
\end{tabular}

${ }^{1}$ T. $b$. rhodesiense (STIB 900 strain, bloodstream trypomastigotes, positive control: melarsoprol); ${ }^{2}$ T. cruzi (Tulahuen C4 strain; intracellular amastigotes, pos. contr.: benznidazole); ${ }^{3}$ L. donovani (MHOM-ET-67/L82 strain, axenic amastigotes, pos. contr.: miltefosine); ${ }^{4}$ P. falciparum (NF54 IEF, pos.: chloroquine); ${ }^{5}$ Cytotoxicity (L6 rat skeletal myoblast cell line, pos.contr.: podophyllotoxin); ${ }^{6}$ Data for the crude extract were previously reported and are repeated here for comparison [2].

On the background of the reported medicinal use as an antimalarial $[8,9]$, it appears noteworthy that the crude extract displayed its highest activity against Pf, even though the $\mathrm{IC}_{50}$ value of $3 \mu \mathrm{g} / \mathrm{mL}$ is relatively moderate. The most active single constituent against this parasite is compound 7 with an $\mathrm{IC}_{50}$ in the same range $(3.2 \mu \mathrm{g} / \mathrm{mL})$, and about equal to that of the pellitorine $(2,3.3 \mu \mathrm{g} / \mathrm{mL})$ [2]. Compound 7 was also found to be the most active compound against Tc. Unfortunately, however, the antiparasitic activity of 7 is not selective. The compound, as the only one in the series, displayed considerable cytotoxicity with an $\mathrm{IC}_{50}$ of only $0.2 \mu \mathrm{g} / \mathrm{mL}$, so further studies on its antiprotozoal activity 
do not appear to be useful. The mixture of $\mathbf{8}$ and $\mathbf{9}$ displayed some activity against Tbr, but with little selectivity. The major component in this mixture (9) is structurally very similar to 7 , and hence is likely to dominate the observed antitrypanosomal as well as cytotoxic activity. The ratio of cytotoxic over antitrypanosomal activity being more favorable for the $8+9$ mixture than for 7 , it could be expected that 9 with its $C_{10}$ acyl moiety, as a pure compound, would be more active and selective against $\mathrm{Tbr}$ than its $\mathrm{C}_{12}$ homologue 7 . In terms of structure-activity relationships, the $p$-hydroxy-substituted phenethyl amide moiety of these two compounds appears to confer higher toxicity to trypanosomatid as well as mammalian cells than the unsubstituted phenethyl amide moiety or the aliphatic amide groups. The other compounds showed only moderate activity against all tested parasites, and also low cytotoxicity. No clear-cut structure-activity relationships became evident for these compounds.

Taken together, the two alkamides $\mathbf{2}$ and $\mathbf{7}$ are likely to be responsible for the major part of the antiplasmodial effect of the crude extract, and thus related to the ethnomedical use of A. pyrethrum as an antimalarial. It must remain an open question at present whether this use was justified and whether, possibly, other compounds from yet-untested fractions contribute to the overall effect.

\section{Materials and Methods}

\subsection{Analytical Procedures and Instruments}

\subsubsection{UHPLC/+ESI-QTOF-MS/MS}

The analytical profiling of samples were performed on the already-described system with the identical method [2].

Sample concentration: concentration of pure compounds: $0.1 \mathrm{mg} / \mathrm{mL}(\mathbf{1}-7)$ or $0.2 \mathrm{mg} / \mathrm{mL}(\mathbf{8}+\mathbf{9})$ in methanol; concentration of fractions: $5 \mathrm{mg} / \mathrm{mL}$; concentration of crude extract: $1 \mathrm{or} 10 \mathrm{mg} / \mathrm{mL}$.

\subsubsection{NMR Spectroscopy}

Nuclear magnetic resonance spectra were recorded on an AS 400 Mercury plus spectrometer (Varian, Palo Alto, CA, USA) at $400\left({ }^{1} \mathrm{H}, 5\right.$ and 6), $600\left({ }^{1} \mathrm{H}, 1-4\right.$ and $\left.7-9\right)$ and $100 \mathrm{MHz}\left({ }^{13} \mathrm{C}\right) \mathrm{CDCl}_{3}$ at room temperature. They were referenced to the solvent signals $\left(\delta_{\mathrm{H}} 7.260 \mathrm{ppm}, \delta_{\mathrm{C}} 77.000 \mathrm{ppm}\right)$.

\subsection{Isolation Process}

\subsubsection{Plant Material}

The plant material (roots of Anacyclus pyrethrum L.; latin description: Pyrethi radix; specification: "scharf" (= "spicy"), powdered) was purchased from Alfred Galke (Bad Grund, Germany). A voucher specimen (\# TS_Apy_01) is deposited at the IPBP herbarium.

\subsubsection{Sohxlet Extraction}

The powdered plant material $(604 \mathrm{~g})$ was exhaustively extracted in two equal portions with dichloromethane (1500 mL each) in a Soxhlet apparatus for $11 \mathrm{~h}$. The extract was evaporated to dryness under reduced pressure, yielding $14 \mathrm{~g}$ of crude extract.

\subsubsection{Gravity Flow Column Chromatography (CC)}

The extract (12.95 g) was separated by CC on $1.2 \mathrm{~kg}$ silica (particle size 0.063 to $0.2 \mathrm{~mm}$; Merck, (Darmstadt, Germany), column dimensions $108 \mathrm{~cm} \times 6 \mathrm{~cm}$ ). The column was covered with aluminum foil to prevent the light-induced polymerization of alkamides with a polyinic structure moiety [16]. The silica was equilibrated at 90:10 $n$-hexane/EtOAc $(2.4 \mathrm{~L})$. The flow was adjusted to $1 \mathrm{~mL} / \mathrm{min}$, and $10 \mathrm{~mL}$ were collected per tube for the first 459 tubes. From tube 460 to tube 2023, $20 \mathrm{~mL}$ were collected per tube. A gradient with an increasing amount of EtOAc was used: $n$-hexane/EtOAc 90:10 (3 L); 80:20 (1.7 L); 70:30 (6.8 L); 60:40 (1.7 L); 50:50 (1 L); 40:60 (3.7 L); $30: 70$ (1 L); and 20:80 (3.7 L). 
Finally, $3 \mathrm{~L}$ of isopropanol was used to obtain the most polar fraction. Related eluates were combined after TLC control (silica gel $60 \mathrm{~F}_{254}$, Merck $(10 \mathrm{~cm} \times 20 \mathrm{~cm})$; detection: anisaldehyde/sulfuric acid, UV $254 \mathrm{~nm}, 366 \mathrm{~nm}$ and daylight; elution: current solvent mixture of the CC column). The fractionation is summarized in Table 2.

Table 2. Column chromatography (CC) fractions of $A$. pyrethrum L. $\left(\mathrm{CH}_{2} \mathrm{Cl}_{2}\right.$ extract).

\begin{tabular}{|c|c|c|c|}
\hline $\begin{array}{c}\text { Fractions and } \\
\text { Combined Eluates * }\end{array}$ & Elution Volume $(\mathrm{mL}) * *$ & Yield (g) & Isolated Compounds \\
\hline I-VIII 1-540 & 4455 & 0.71977 & \\
\hline IX 541-550 & 200 & 0.0921 & \\
\hline$\times 551-565$ & 320 & 0.1638 & \\
\hline XI 566-585 & 300 & 0.0801 & \\
\hline XII 586-625 & 670 & 0.3187 & \\
\hline XIII 626-660 & 530 & 0.4814 & \\
\hline XIV 661-690 & 410 & 0.2181 & \\
\hline XV 691-720 & 370 & 0.1548 & $2,3,4$ \\
\hline XVI 721-819 & 1020 & 0.3595 & \\
\hline XVII 820-890 & 980 & 0.2426 & \\
\hline XVIII 891-909 & 330 & 0.0696 & \\
\hline XIX 910-940 & 510 & 0.1803 & 1 \\
\hline XX 941-1010 & 760 & 0.3141 & $1,5,6$ \\
\hline XXI 1011-1080 & 840 & 0.5080 & \\
\hline XXII 1081-1140 & 850 & 0.5072 & $8,9,10$ \\
\hline XXIII 1141-1200 & 710 & 0.1973 & \\
\hline XXIV 1201-1210 & 83 & 0.0244 & \\
\hline XXV 1211-1225 & 120 & 0.0381 & \\
\hline XXVI 1226-1280 & 490 & 0.1175 & \\
\hline XXVII 1281-1319 & 340 & 0.0619 & \\
\hline XXVIII 1320-1335 & 230 & 0.0493 & \\
\hline XXIX 1336-1380 & 780 & 0.1580 & \\
\hline XXX 1381-1410 & 480 & 0.1136 & \\
\hline XXXI 1411-1470 & 950 & 0.1796 & \\
\hline XXXII 1471-1750 & 4420 & 0.5834 & \\
\hline XXXIII 1751-1830 & 1230 & 0.0782 & \\
\hline XXXIV 1831-1875 & 540 & 0.0508 & \\
\hline XXXV 1876-1885 & 80 & 0.7643 & \\
\hline XXXVI 1886-1919 & 520 & 0.3215 & \\
\hline XXXVII 1920-1959 & 800 & 0.1256 & \\
\hline \multirow[t]{3}{*}{ XXXVIII 1960-2023 } & 1080 & 0.1762 & \\
\hline & Total: & Total: & \\
\hline & 25,398 & 7.4498 & \\
\hline
\end{tabular}

* tube 1-459: $10 \mathrm{~mL}$; tube 460-2023: $20 \mathrm{mL;}$;* eluate amounts determined volumetrically.

\subsubsection{Purification by Preparative High Performance Liquid Chromatography (HPLC/UV-DAD)}

The preparative HPLC isolation of all alkamides was performed on a Jasco (Groß-Umstadt, Germany) prep. HPLC system (pump: PU-2087 plus; diode array detector MD 2018 plus; column thermostat CO 2060 plus; autosampler AS 2055 plus; LC Net II ADC Chromatography Data Solutions; sample injection loop: $2000 \mu \mathrm{L})$ on a Reprosil $100 \mathrm{C}-18$ column $(5 \mu \mathrm{m}, 250 \mathrm{~mm} \times 20 \mathrm{~mm})$ column (precolumn: C-18, $5 \mu \mathrm{m}, 30 \mathrm{~mm} \times 20 \mathrm{~mm}$ ) with a binary gradient (A: water (Millipore); B: acetonitrile (HPLC grade)) at $15 \mathrm{~mL} / \mathrm{min}$ with: 0 to $5 \mathrm{~min}$ : linear from $40 \% \mathrm{~B}$ to $65 \% \mathrm{~B} ; 5$ to $30 \mathrm{~min}$ : isocratic $65 \% \mathrm{~B} ; 30 \mathrm{~min}$ to $40 \mathrm{~min}$ : linear from $65 \% \mathrm{~B}$ to $100 \% \mathrm{~B} ; 40 \mathrm{~min}$ to $50 \mathrm{~min}$ : isocratic $100 \% \mathrm{~B}$. The subfractions XIX and XV were each dissolved in a concentration of $10 \mathrm{mg} / \mathrm{mL}$ acetonitrile and injected in portions of $400 \mu \mathrm{L}$. The subfractions XX and XXII were dissolved in a concentration of 10 $\mathrm{mg} / \mathrm{mL}$ acetonitrile/water (70:30) each and injected in portions of $400 \mu \mathrm{L}$. Pellitorine (2), as well as compounds 3 and 4 were isolated as white powders in yields of $0.6 \mathrm{mg}$ (2), $0.8 \mathrm{mg}$ (3), and $0.8 \mathrm{mg}$ (4) 
from $108 \mathrm{mg}$ of fraction XV. Anacycline (1) was purified in a yield of $3.5 \mathrm{mg}$ from $36 \mathrm{mg}$ of fraction XIX. From a $120 \mathrm{mg}$ of fraction XX, 9.2 mg of (5), $2.2 \mathrm{mg}$ of (6) and $12.3 \mathrm{mg}$ of anacycline (1) were obtained. A yield of $7.8 \mathrm{mg}$ of compound (7) could be purified from a $72 \mathrm{mg}$ of fraction XXII. Furthermore, compounds 8 and 9 were isolated as mixture (1:4) in a yield of $21.1 \mathrm{mg}$ from a $72 \mathrm{mg}$ of fraction XXII. The compounds isolated from fraction XXII were obtained as yellowish-white powders.

\subsubsection{Analytical Data}

Tetradeca-2E,4E-dien-8,10-diynoic acid isobutylamide (anacycline, 1). UHPLC/+ESI-QqTOF MS: Rt $7.42 \mathrm{~min}$, MS (m/z): 272.2046 (calcd. for $\left.\mathrm{C}_{18} \mathrm{H}_{26} \mathrm{NO}^{+}: 272.2009\right) ;{ }^{1} \mathrm{H}-\mathrm{NMR}\left(600 \mathrm{MHz}, \mathrm{CDCl}_{3}\right.$; $\delta(\mathrm{ppm})$, mult., $J(\mathrm{~Hz})): 7.18$ (dd, 11,15; H-3); 6.19 (dd, 11, 15; H-4); 6.07 (dt, 7, 15; H-5); 5.79 (d, 15; H-2); 5.48 (br s; NH); 3.17 (t (2H), 6, 7; H-2'); 2.38 (m (4H); H-6, H-7); 2.23 (t (2H), 7; H-12); 1.80 (sept, 7; H-3'); 1.55 (tq, (2H), 7; H-13); 0.98 (t (3H), 7; H-14); 0.93 (d (6H), 7; H-4' , H-5').

Deca-2E,4E-dienoic acid isobutylamide (pellitorine, 2). UHPLC/+ESI-QqTOF MS: Rt $7.26 \mathrm{~min}$, MS $(\mathrm{m} / \mathrm{z}$ ): $224.2022[\mathrm{M}+\mathrm{H}]^{+}$; calcd. for $\mathrm{C}_{14} \mathrm{H}_{26} \mathrm{NO}^{+}: 224.2009 ;{ }^{1} \mathrm{H}-\mathrm{NMR}\left(600 \mathrm{MHz}, \mathrm{CDCl}_{3} ; \delta(\mathrm{ppm})\right.$, mult., $J(\mathrm{~Hz})$ ): 7.19 (dd, 10, 15; H-3); 6.13 (dd, 10, 15; H-4); 6.07 (dt, 7; 15; H-5); 5.74 (d, 15; H-2); 5.43 (br s; NH); 3.17 $\left(\mathrm{dd}(2 \mathrm{H}), 6 ; \mathrm{H}-2^{\prime}\right) ; 2.14(\mathrm{dt},(2 \mathrm{H}), 7,7 ; \mathrm{H}-6) ; 1.80$ (sept, 7; H-3'); $1.42(\mathrm{tt},(2 \mathrm{H}), 7,7 ; \mathrm{H}-7) ; 1.28(\mathrm{~m}(4 \mathrm{H})$; H-8, H-9 overlapping signals); 0.93 (d (6H), 7; H-4' , 5'); 0.89 (t (3H), 7; H-10).

Deca-2E,4E,9-trienoic acid isobutylamide (9,10-dehydropellitorine, 3). UHPLC/+ESI-QqTOF MS: Rt $6.72 \mathrm{~min}, \mathrm{MS}(\mathrm{m} / \mathrm{z})$ : $222.1855[\mathrm{M}+\mathrm{H}]^{+}$; calcd. for $\mathrm{C}_{14} \mathrm{H}_{24} \mathrm{NO}^{+}$: $222.1855 ;{ }^{1} \mathrm{H}-\mathrm{NMR}$ (600 MHz, $\mathrm{CDCl}_{3} ; \delta$ (ppm), mult., J (Hz)): 7.19 (dd, 10, 15; H-3); 6.14 (dd, 10, 15; H-4); 6.06 (dt, 15, 7; H-5); 5.81 (dt, 7, 10; H-9); 5.75 (d, 15; H-2); 5.44 (br s; NH); 5.01 (ddt, 2, 2, 17; H-10 trans); 4.96 (ddt, 1, 2, 10; H-10 cis); 3.17 (t (2H), 6; H-2'); 2.17 (dt (2H), 7, 7; H-6); 2.06 (dt (2H) 7,7; H-8); 1.80 (sept, 7; H-3'); $1.52\left(\mathrm{~m}(2 \mathrm{H}), 7\right.$; H-7) overlapping signals; $0.93\left(\mathrm{~d}(6 \mathrm{H}), 7 ; \mathrm{H}-4^{\prime}, \mathrm{H}-5^{\prime}\right) ;{ }^{13} \mathrm{C}-\mathrm{NMR}\left(150 \mathrm{MHz}, \mathrm{CDCl}_{3}\right.$; $\delta$ (ppm), mult.: 168.1, (s, C-1); 142.8 (d, H-5); 141.4 (d, C-3); 138.5 (d, C-9); 128.7 (d. C-4); 122.0 (d, C-2); 115.0 (t, C-10); 47.1 (t. C-2'); 33.3 (t, C-8); 32.4 (t, C-6); 28.8 (d, C-3'); 28.1 (t, C-7); 20.3 (q, C-4' + C-5'); All assignments confirmed by HSQC and HMBC experiments.

Deca-2E,4E-dienoic acid 2-phenylethylamide (4). UHPLC/+ESI-QqTOF MS: Rt $7.67 \mathrm{~min}$, MS $(\mathrm{m} / \mathrm{z})$ : $272.2026[\mathrm{M}+\mathrm{H}]^{+}$; calcd. for $\mathrm{C}_{18} \mathrm{H}_{26} \mathrm{NO}^{+}: 272.2009 ;{ }^{1} \mathrm{H}-\mathrm{NMR}\left(600 \mathrm{MHz}, \mathrm{CDCl}_{3} ; \delta\right.$ (ppm), mult., $J(\mathrm{~Hz})): 7.31\left(\mathrm{t}(2 \mathrm{H}) 7 ; \mathrm{H}-3^{\prime \prime}, \mathrm{H}-5^{\prime \prime}\right) ; 7.23\left(\mathrm{t}, 7 ; \mathrm{H}-4^{\prime \prime}\right) ; 7.20\left(\mathrm{~d}(2 \mathrm{H}) 7 ; \mathrm{H}-2^{\prime \prime}, \mathrm{H}-6^{\prime \prime}\right) ; 7.18$ (dd, 10, 15; H-3); 6.11 (dd, 10, 15; H-4); 6.07 (dt, 7, 15; H-5); 5.67 (d, 15, H-2); 5.40 (br s; NH); 3.60 (dt (2H), 6, 7; H-2'); $2.85\left(\mathrm{t}(2 \mathrm{H}), 7 ; \mathrm{H}-3^{\prime}\right) ; 2.14(\mathrm{dt}(2 \mathrm{H}), 7,7 ; \mathrm{H}-6) ; 1.41(\mathrm{tt}(2 \mathrm{H}), 7,7 ; \mathrm{H}-7)$ overlapping signals; $1.28(\mathrm{~m}(4 \mathrm{H})$; $\mathrm{H}-8, \mathrm{H}-9)$ overlapping signals; $0.88(\mathrm{t}(3 \mathrm{H}), 7 ; \mathrm{H}-10)$.

Undeca-2E,4E-dien-8,10-diynoic acid isopentylamide (5). UHPLC/+ESI-QqTOF MS: Rt $6.55 \mathrm{~min}$, MS (m/z): $244.1732[\mathrm{M}+\mathrm{H}]^{+}$; calcd. for $\mathrm{C}_{16} \mathrm{H}_{22} \mathrm{NO}^{+}$: $244.1696 ;{ }^{1} \mathrm{H}-\mathrm{NMR}\left(400 \mathrm{MHz}, \mathrm{CDCl}_{3} ; \delta\right.$ (ppm), mult., $J(\mathrm{~Hz})): 7.17(\mathrm{dd}, 11,15 ; \mathrm{H}-3) ; 6.19(\mathrm{dd}, 11,15 ; \mathrm{H}-4) ; 6.04(\mathrm{dt}, 7,15 ; \mathrm{H}-5) ; 5.78$ (d, 15, H-2); 5.48 (br s; NH); 3.35 (dt (2H), 6, 7; H-2'); 2.38 (m, (4H); H-6, H-7); 1.98 (s; H-11); 1.63 (sept, 7; H-4'); $1.42(\mathrm{dt}(2 \mathrm{H}), 8,7$; $\left.\mathrm{H}-3^{\prime}\right) ; 0.92\left(\mathrm{~d}(6 \mathrm{H}), 7, \mathrm{H}-4^{\prime}, \mathrm{H}-5^{\prime}\right)$.

Tetradeca-2E,4E,12Z-trien-8,10-diynoic acid isobutylamide (6). UHPLC/+ESI-QqTOF MS: Rt 7.23 min, MS ( $m / z)$ : $270.1881[\mathrm{M}+\mathrm{H}]^{+}$; calcd. for $\mathrm{C}_{18} \mathrm{H}_{24} \mathrm{NO}^{+}: 270.1852 ;{ }^{1} \mathrm{H}-\mathrm{NMR}\left(400 \mathrm{MHz}, \mathrm{CDCl}_{3} ; \delta(\mathrm{ppm})\right.$, mult., J (Hz)): 7.19 (dd, 11, 15; H-3); 6.21 (dd, 11, 15; H-4); 6.12 (dq, 7, 11; H-13); 6.08 (dt, 6, 15; H-5); $5.80(\mathrm{~d}, 15, \mathrm{H}-2) ; 5.50(\mathrm{dt}, 11,1 ; \mathrm{H}-12) ;\left(5.47(\mathrm{br} \mathrm{s}, \mathrm{NH}) ; 3.17\left(\mathrm{dd}(2 \mathrm{H}), 6,7 ; \mathrm{H}-2^{\prime}\right) ; 2.46(\mathrm{dt}(2 \mathrm{H}), 6,7 ; \mathrm{H}-6)\right.$; 2.41 (t, (2H) 7; H-7); 1.91 (dd (3H) 7, 2; H-14); 1.80 (sept, 7, H-3'); 0.93 (d (6H), 7, H-4' , H-5').

Dodeca-2E,4E-dienoic acid 4-hydroxy-2-phenylethylamide (7). UHPLC/+ESI-QqTOF MS: Rt $7.66 \mathrm{~min}$, MS $(m / z): 316.2273[\mathrm{M}+\mathrm{H}]^{+}$; calcd. for $\mathrm{C}_{20} \mathrm{H}_{30} \mathrm{NO}_{2}{ }^{+}$: $316.2271 ;{ }^{1} \mathrm{H}-\mathrm{NMR}\left(600 \mathrm{MHz}, \mathrm{CDCl}_{3}\right.$; $\delta(\mathrm{ppm})$, mult., $J(\mathrm{~Hz})): 7.18$ (dd, 10, 15; H-3); 7.03 (d (2H) 8; H-2" , H-6" $\left.{ }^{\prime \prime}\right) ; 6.79$ (d (2H) 8; H-3" , H-5'); 6.10 (dd, 10, 15; H-4); 6.06 (dt, 7, 15; H-5); 5.68 (d, 15; H-2); 5.52 (br s; NH); 3.56 (dt (2H), 7, 7; 
H-2'); 2.76 (t, (2H) 7, H-3'); 2.13 (dt, 7, 7; H-6); 1.40 (tt, 7, 7; H-7); 1.27 (m (8H); H-8, H-9, H-10, H-11) overlapping signals; $0.92\left(\mathrm{~d}(6 \mathrm{H}), 7, \mathrm{H}-4^{\prime}, 5^{\prime}\right) ; 0.88(\mathrm{t}(3 \mathrm{H}), 7, \mathrm{H}-12)$.

Undeca-2E,4E-dien-8,10-diynoic acid 2-phenethylamide (8). UHPLC/+ESI-QqTOF MS: Rt $6.53 \mathrm{~min}$, MS ( $m / z)$ : 278.1542 (calcd. for $\left.\mathrm{C}_{19} \mathrm{H}_{20} \mathrm{NO}^{+}: 278.1539\right) ;{ }^{1} \mathrm{H}-\mathrm{NMR}\left(600 \mathrm{MHz}, \mathrm{CDCl}_{3} ; \delta\right.$ (ppm), mult., $J(\mathrm{~Hz})): 7.31\left(\mathrm{t}(2 \mathrm{H}) 7 ; \mathrm{H}-3^{\prime \prime}, \mathrm{H}-5^{\prime \prime}\right) ; 7.23\left(\mathrm{t}, 7 ; \mathrm{H}-4^{\prime \prime}\right) ; 7.20\left(\mathrm{~d}(2 \mathrm{H}) 7 ; \mathrm{H}-2^{\prime \prime}, \mathrm{H}-6^{\prime \prime}\right) ; 7.18(\mathrm{dd}, 11,15 ; \mathrm{H}-3)$; 6.17 (dd, 11, 15; H-4); 6.06 (m [dt]; H-5); 5.56 (br s; NH); 3.61 (dt (2H), 6, 7; H-2'); 2.85 (t (2H), 7; H-3'); 2.38 (m (4H); H-6, 7); 1.98 (s; H-11).

Deca-2E,4E-dienoic acid 4-hydroxy-2-phenylethylamide (9) UHPLC/+ESI-QqTOF MS: Rt 6.66 min, MS $(m / z): 288.1973[\mathrm{M}+\mathrm{H}]^{+}$; calcd. for $\mathrm{C}_{18} \mathrm{H}_{26} \mathrm{NO}_{2}{ }^{+}$: $288.1958 ;{ }^{1} \mathrm{H}-\mathrm{NMR}\left(600 \mathrm{MHz}, \mathrm{CDCl}_{3}\right.$; $\delta(\mathrm{ppm})$, mult., $J(\mathrm{~Hz})): 7.19$ (dd, 10, 15; H-3); $7.02\left(\mathrm{~d}(2 \mathrm{H}) 8 ; \mathrm{H}-2^{\prime \prime}, \mathrm{H}-6^{\prime \prime}\right) ; 6,80\left(\mathrm{~d}(2 \mathrm{H}) 8 ; \mathrm{H}-3^{\prime \prime}\right.$, $\left.\mathrm{H}-5^{\prime \prime}\right) ; 6.10$ (dd, 10, 15; H-4); 6.06 (m [dt]; H-5); 5.69 (d, 15, H-2); 5.56 (br s; NH); 3.55 (dt (2H), 6, 7; H-2'); $2.76\left(\mathrm{t}(2 \mathrm{H}), 7 ; \mathrm{H}-3^{\prime}\right) ; 2.13(\mathrm{dt},(2 \mathrm{H}) 7,7 ; \mathrm{H}-6) ; 1.41$ (tt (2H), 7; H-7); $1.29(\mathrm{~m}(4 \mathrm{H}) ; \mathrm{H}-8, \mathrm{H}-9) ; 0.88(\mathrm{t}(3 \mathrm{H})$, 7, $\mathrm{H}-10)$.

All analytical data were in full agreement with literature data: compounds 1, 5, 6 [11], 2, 8 [12], 4 [13], 7,9 [15].

\subsection{In Vitro Assays and $\mathrm{IC}_{50}$ Determination}

Tests for antiprotozoal activities were carried out using established standard protocols at the Swiss Tropical and Public Health Institute (Swiss TPH, Basel, Switzerland). The assays and the $\mathrm{IC}_{50}$ determinations were performed essentially as described previously [17]. The compounds used as positive controls in the various bioassays (see Table 1) were of commercial origin, with the exception of melarsoprol, which was a gift from the WHO. Their purity (generally $>95 \%$ ) was specified by the manufacturers. The purity of test compounds was assessed by UHPLC/MS analyses and found to be $>90 \%$ in case of compounds 1-6 and $>80 \%$ in case of 7 . Compounds $8+9$ represented a mixture in a ratio of approximately 1:4 (Figure S10).

\section{Conclusions}

The present study adds to the knowledge on the alkamides in roots of $A$. pyrethrum, a medicinal drug used since ancient times. Compounds 3, 4, and 5 are reported as constituents of A. pyrethrum for the first time. Compound 3-deca-2E,4E,9-trienoic acid isobutylamide (9,10-dehydropellitorine)-is a hitherto-undescribed natural product. In the case of compound 6, the configuration of the 12,13-double bond, which had previously been reported as $E$ (although without support by any data), could be unambiguously assigned as $Z$. The reported ethnomedicinal use of $A$. pyrethrum as an antimalarial might be explained by the activity of its lipophilic constituents, as the dichloromethane extract presented moderate in vitro activity against Plasmodium falciparum, which is in the same range as that of the most active alkamides isolated, namely pellitorine (2) and dodeca- $2 E, 4 E$-dienoic acid 4-hydroxy-2-phenylethylamide (7), of which the latter also presented considerable toxicity against mammalian cells. However, the overall antiparasitic activity is low and does not warrant further exploitation.

Supplementary Materials: Supplementary materials are available online. The NMR and mass spectra of all isolates are provided as supplementary Figures S1-SXY available online.

Acknowledgments: Thanks are due to C. Thier and J. Sendker for measuring NMR and mass spectra, respectively. We thank S. Keller-Maerki and R. Rocchetti for assistance with parasite assays. This study is an activity within the ResearchNetwork Natural Products against Neglected Diseases (ResNetNPND): http:/ /www/uni-muenster.de/ ResNetNPND/.

Author Contributions: J.B.A. supervised the phytochemical parts of the work and prepared a draft manuscript. C.M. isolated the compounds. M.K. and R.B. performed he biological assays. T.J.S. initiated the study, coordinated and supervised the project and prepared the final manuscript.

Conflicts of Interest: The authors declare no conflict of interest. 


\section{References}

1. Greger, H. Alkamides: A critical reconsideration of a multifunctional class of unsaturated fatty acid amides. Phytochem. Rev. 2015. [CrossRef]

2. Althaus, J.B.; Kaiser, M.; Brun, R.; Schmidt, T.J. Antiprotozoal Activity of Achillea ptarmica (Asteraceae) and Its Main Alkamide Constituents. Molecules 2014, 19, 6428-6438. [CrossRef] [PubMed]

3. Silveira, N.; Saar, J.; Santos, A.D.C.; Barison, A.; Sandjo, L.P.; Kaiser, M.; Schmidt, T.J.; Biavatti, M.W. A New Alkamide with an Endoperoxide Structure from Acmella ciliata (Asteraceae) and Its in Vitro Antiplasmodial Activity. Molecules 2016, 21, 765. [CrossRef] [PubMed]

4. Himmelreich, S.; Källersjö, M.; Eldenäs, P.; Oberprieler, C. Phylogeny of southern hemisphere Compositae-Anthemideae based on nrDNA ITS and cpDNA ndhF sequence information. Plant Syst. Evol. 2008, 272, 131-153. [CrossRef]

5. Oberprieler, C.; Himmelreich, S.; Vogt, R. A new subtribal classification of the tribe Anthemideae (Compositae). Willdenowia 2007, 37, 89-114. [CrossRef]

6. Watson, L.E.; Evans, T.M.; Boluarte, T. Molecular Phylogeny and Biogeography of Tribe Anthemideae (Asteraceae), Based on Chloroplast Gene ndhF. Mol. Phylogenet. Evol. 2000, 15, 59-69. [CrossRef] [PubMed]

7. Greger, H. Ungesättigte Säureamide-Ein chemisches Merkmal der Gattung Achillea. Planta Med. 1982, 45, 142-143. [CrossRef] [PubMed]

8. Dioskurides, P. Kräuterbuch deß Uralten unnd in aller Welt berühmtesten Griechischen Scribenten Pedacii Dioscorides Anazarbaei; Dantz, J.; Uffenbach, P., Translators; Kempfer: Franckfurt am Mayn, Germany, 1614.

9. Adams, M.; Alther, W.; Kessler, M.; Kluge, M.; Hamburger, M. Malaria in the renaissance: Remedies from European herbals from the 16th and 17th century. J. Ethnopharmacol. 2011, 133, 278-288. [CrossRef] [PubMed]

10. Zimmermann, S.; Thomi, S.; Kaiser, M.; Hamburger, M.; Adams, M. Screening and HPLC-Based Activity Profiling for New Antiprotozoal Leads from European Plants. Sci. Pharm. 2012, 80, 205-213. [CrossRef] [PubMed]

11. Kuropka, G.; Glombitza, K.W. Further Polyenic and Polyynic Carboxamides and Sesamin from Achillea ptarmica. Planta Med. 1987, 53, 440-442. [CrossRef] [PubMed]

12. Hofer, O.; Greger, H.; Robien, W. ${ }^{13} \mathrm{C}-\mathrm{NMR}$ and ${ }^{1} \mathrm{H}$ lanthanide induced shifts of naturally occurring alkamides with cyclic amide moieties-Amides from Achillea falcata. Tetrahedron 1986, 42, 2707-2716. [CrossRef]

13. Greger, H.; Hofer, O. Highly Unsaturated Isopentyl Amides from Achillea wilhelmsii. J. Nat. Prod. 1987, 50, 1100-1107. [CrossRef]

14. Jente, R.; Bonnet, P.H.; Bohlmann, F. Polyacetylenverbindungen, 206. Über die Inhaltsstoffe von Anacyclus pyrethrum DC. Chem. Ber. 1972, 105, 1694-1700. [CrossRef]

15. Burden, R.S.; Crombie, L. Amides of vegetable origin. Part XII. A new series of Alka-2,4-dienoic Tyramine-amides from Anacyclus pyrethrum D.C. (Compositae). J. Chem. Soc. C 1969, 19, 2477-2481. [CrossRef]

16. Bohlmannn, F.; Inhoffen, E. Polyacetylenverbindungen (XVI. Mitteil.) Synthese des Anacyclins. Chem. Ber. 1956, 89, 1276-1281. [CrossRef]

17. Schmidt, T.J.; Nour, A.M.M.; Khalid, S.A.; Kaiser, M.; Brun, R. Quantitative Structure-Antiprotozoal Activity Relationships of Sesquiterpene Lactones. Molecules 2009, 14, 2062-2076. [CrossRef] [PubMed]

Sample Availability: Samples of the compounds 1, 5, 6, 7 and the mixture of $8+9$ are available from the authors. 